\author{
Марина Ткачук \\ Інститут української мови НАН України \\ Київ \\ ORCID: 0000-0002-4165-7741; e-mail: tkachuk_maryna@ukr.net
}

\title{
Діалектологічна цінність фольклорних джерел
}

Реферат: У статті узагальнено основні передумови, які визначають можливість потенційного використання фольклорно-етнографічних джерел для розв'язання лінгвістичних, зокрема діалектологічних, проблем. Проаналізовано такі позатекстові чинники, як: методику записування фольклорних текстів, зокрема точність відтворення діалектних особливостей у різних фольклорно-етнографічних виданнях; можливість точного ареального співвіднесення фольклорного твору 3 місцем його творення / побутування; наявність додаткової позалінгвальної інформації, важливої для лінгвіста-дослідника. Розглянуто текстотвірні фактори, які накладають обмеження на використання фольклорних текстів у діалектологічних дослідженнях, як-от віршована / прозова форма твору; жанротвірні характеристики тощо.

Ключові слова: типи діалектологічних джерел, фольклорний текст, діалектологічні дослідження, евристичний потенціал фольклорного тексту.

\begin{abstract}
The dialectological value of the folklore sources. The article summarizes the main prerequisites for potential use of folklore and ethnographic sources for solving linguistic problems, including dialectological ones. Attention is given to records of Ukrainian folklore - from the late 19th century to the latest ones. The non-textual factors like methods of recording folklore texts are analysed, in particular the accuracy of reproducing dialectal features in various folklore and ethnographic publications, the possibility of an exact correlation between the area of a folklore work and the place of its creation/ existence and the availability of additional extralingual information, which is of importance to a linguist. Consideration is given to the text-forming factors that impose some restrictions on using folklore texts in dialectological research (like the poetic/prose form of a work, genre forming characteristics, etc.). Emphasis has been placed on the special value of folklore sources to the identification of archaic linguistic units and phenomena, the possibility of using archaeological methods in the study of folklore texts.
\end{abstract}

Keywords: types of dialectological sources, folklore text, dialectological research, heuristic potential of folklore text.

Переорієнтація на текстоцентричний підхід у дослідженнях українських діалектів закономірно загострює увагу до текстів фольклорних як джерела лінгвістичних студій. Проблемі діалект $і$ фольклорний текст присвятили свої праці О.О. Потебня, О.О. Шахматов, Р. Якобсон, Ф.П. Сороколєтов, Й.А. Оссовецький, П.Г. Богатирьов, А.В. Десницька, Д. Брозович, Є. Бартмінський, Є. Серотюк, П.Ю. Гриценко, Г.Л. Аркушин, Ю.В. Громик, В.М. Ляшук та ін. Зауважимо, що 
в українському мовознавстві фольклорні тексти частіше розглядали 3 позиції співвідношення і взаємодії з мовою літературною, звертаючи також увагу на лінгвопоетику (С.Я. Срмоленко, А.М. Поповський, Н.О. Данилюк та ін.). До діалектологічного аналізу фольклорних текстів звертаються дослідники різних українських діалектних ареалів, зокрема Західного Полісся (Г.Л. Аркушин, Ю.В. Громик, Р.С. Зінчук, Ю.В. Грицевич, О. Бойчук), Середнього Полісся (П.Ю. Гриценко), Поділля (Б.О. Коваленко, І.В. Гороф'янюк).

Підкреслюючи пріоритетність для діалектологічних досліджень тих текстів, які створюються в момент оповіді (Гриценко 2003, XV), наголосимо на можливості й важливості аналізу тексту відтворюваного (яким є текст фольклорний), що наслідує прототекст, зберігаючи (різною мірою) елементи питомого мовного середовища оповідача, відтворює (інтерпретує) його у своєму часовому зрізі.

Дослідники віддавна наголошують на важливості фольклорних текстів як джерела для дослідження говіркового мовлення. До таких текстів у широкому розумінні належать не лише фольклорні твори різних жанрів (поетичні, прозові), а й спонтанні усні наративи різної етнографічної тематики, записувані збирачами фольклору й етнографами, різні фольклористичні й етнографічні розвідки, що містять мовні риси (лексику, фонетичні, словотвірні, морфологічні особливості), характерні для відповідного регіону чи окремого населеного пункту. Окремим джерелом є фольклорні ілюстрації в різних лексиконах; наприклад, широкий фольклорний матеріал використано як ілюстративний матеріал до словникових статей у Матеріалах до словника украӥнських говірок Закарпатської області М.А. Грицака (2017).

Усі ці фольклорні джерела мають для діалектолога різну евристичну цінність, оскільки різняться не лише за «якістю» відтворюваного матеріалу, а й багатьма іншими рисами.

Стаття є спробою узагальнити основні передумови, які визначають можливість потенційного використання фольклорно-етнографічних джерел для розв'язання лінгвістичних, зокрема діалектологічних, проблем.

Можливість використання фольклорних текстів лінгвістом-дослідником залежить від факторів, які, на нашу думку, можна умовно означити як власне текстологічні та позатекстові, які, утім, між собою тісно пов'язані.

До позатекстових чинників належить процес записування тексту, настанови записувачів та їхня методика (див.: Гриценко 2014, 145-146). О.Ю. Бріцина зауважує, що науковці різних країн висловлюють занепокоєння якістю матеріалів, а також «відзначають залежність теоретичних побудов від надійності джерел, невідповідність між теоретичними постулатами та реальною дослідницькою і видавничою практикою» (Бріцина 2003, 26). Тож до кожного конкретного тексту дослідник мусить підходити окремо.

Уже в XIX ст. записувачі фольклорних текстів усвідомлювали необхідність дотримання фонетичного принципу у відтворенні записуваних матеріалів і збереженні особливостей місцевої вимови. На цьому, зокрема, наголошували П.П. Чубинський (1872, XIX), В.М. Гнатюк (1897, XIII), О.Н. Малинка (СМФ, 2) у передмовах до видань етнографічних записів; І.Я. Франко, звертаючись до етнографів-записувачів, зазначав: «Правопис записів має бути шкільний, але місцеві 
прикмети говору мають бути задержані» (Франко 1982, 412); водночас дослідники дорікали тим записувачам, які не зберігали «оригінальних рис» записуваних творів, та редакторам збірок таких матеріалів, які мало уваги приділяли діалектним особливостям (Франко 1980, 212-213).

Друк таких матеріалів часто був ускладнений - як технічно, так і відсутністю єдиної системи запису. Наприклад, у Збірнику матеріалів із малоросійського фольклору (Чернігівської, Волинської, Полтавської і деяких інших губерній), зібраного О.Н. Малинкою (1902 р.), зазначено, що деякі знаки (ідеться насамперед про позначення поліських дифтонгів) були неправильно замінені в типографії на знаки монофтонгів:

Въ своей рукописи я отмъчалъ знаками $y$ и ю съ чертой наверху дифтонги $y b l(y э)$ и юи (представляющіе промежуточную ступень при переходъ звуковъ $o$ и $e$ въ украинское $u$ : конь-куынь-кинь; тётка-тюитка-титка). Въ типографіи такихъ знаковъ не оказалось, и потому при наборђ они неправильно были замънены простыми буквами $y$ и ю. По той же причинъ, т. е. всльдствіе недостатка въ типографіи необходимыхъ буквъ, и знакъ ё не вездъ выдержанъ и замънялся по большей части буквой е (СМФ, XXII).

Незважаючи на такі складнощі, записані матеріали, зокрема із Західного Полісся, виразно відображають говіркові риси, напр.: твердість $p$ перед $а$ (раба 'ряба' [СМФ, 193], мирай 'міряй' [СМФ, 197], пор.: [АУМ, II, к. 115]); перехід $o \rightarrow y$ в слабкій позиції (сукиру, кужуха [СМФ, 155], чулувикъ [СМФ, 198]; і навіть розширюють інформацію, подану в Aтласі украӥнської мови. Так, матеріали О.Н. Малинки дозволяють стверджувати, що нейтралізація опозиції $o-y$ в ненаголошеній позиції давніше мала ширшу географію (район м. Остріг - с. Стригани) порівняно зі свідченням (АУМ, ІІ, к. 55), де зафіксовано вужчі мікроареали.

Багато інших текстів фольклорно-етнографічних експедицій також подано орфографічною транскрипцією, але зі збереженням говіркових рис, див., напр., записи українських народних пісень Ф.М. Колесси (1902); матеріали О. Кольберга (Kolberg 1964, 52) тощо. Доволі точно в записах 20-х років ХХ століття було відтворено говіркові риси різних мовних рівнів середньополіської говірки с. Бехи на Житомирщині (Кравченко 2009), про що зазначено в спеціальній розвідці (Гриценко 2014).

Фольклорні видання новіших записів, здійснених в останні десятиліття, різною мірою відображають автентичні риси відповідних говірок. Таким, наприклад, є видання Така житка В. Борисенко, де інтерв'ю інформантів - мешканців Чорнобильської зони, носіїв середньополіських говірок Поліського р-ну Київської області, - подано орфографічним записом зі збереженням окремих локальних мовленнєвих рис у дещо спрощеному вигляді. Зокрема, серед виразних середньополіських рис у говірці с. Залішани на місці давнього $о$ в новому закритому складі зафіксовано звуки [y], [оу] : вун, а воун був сирота, на двоур (Борисенко 2011, 188-193), в атласі Т.В. Назарової - це зона збереження дифтонга [уо] в цій позиції (ЛАНП, к. 8); заступлення $i \rightarrow a$ : сядаєм, відображено закінчення

1 Припускаємо, що мається на увазі дифтонг [уо]. 
-m у дієсловах 3 ос. мн. теп. ч.: вербуют, гаворат; нестягнені форми прикметників та займенників прикметникового типу відмінювання: оцюю халупу, нашії ікони (Борисенко 2011, 191-194) тощо.

Чималий фольклорно-етнографічний текстовий матеріал з українських говірок різних наріч представлено в багатотомовому виданні Етнографічний образ сучасної України (ЕОСУ). Більшість текстів відображають основні фонетичні, морфологічні й лексичні риси мовлення інформантів (див., напр., наративи з волинських та західнополіських говірок про традиційне народне вбрання). Однак після ретельного аналізу можна зауважити, що деякі з них зазнали значного втручання редакторів чи заміщення оригінального тексту науковою оповіддю зі збереженням лише окремих діалектних лексем: див., наприклад, наративи із закарпатських говірок - с. Верховина-Бистра, Лубня Великоберезн. р-ну, с. Новоселиця, Хижа Виноградів. р-ну (ЕОСУ X, 151-155) та ін. У багатьох інших текстах цього видання фонетика, граматика й лексичний склад говірки представлені 3 огляду на індивідуальні настанови та компетенцію записувача / транскриптора, проте в плані синтаксичному й текстологічному (текстотворення, структури й організації тексту) ці текстові зразки неінформативні, становлять компіляцію фрагментів різного обсягу, записаних від різних інформантів без зазначення умов запису ${ }^{2}$, об'єднаних і представлених як єдиний цілісний текст волею дослідника-інтерпретатора.

Найцінніші з погляду збереження мовних рис говірки записи етнолінгвістичні, адже вони спрямовані як на відтворення традиційної культури, так і на точну фіксацію діалектних рис, а дослідник-записувач й транскриптор мають достатню кваліфікацію для якнайточнішого відтворення діалектних рис у письмово переданому тексті; див., напр.: (НЕC).

Другий важливий аспект методики записування й представлення матеріалів ïx точна паспортизація: від кого, де, коли та ким було записано той чи інший текст; при цьому мають бути зазначені дата народження та освіта інформанта. Така практика вже усталена в сучасній діалектології та фольклористиці й етнографії, проте в давніших матеріалах здебільшого зафіксовано лише місце запису (СМФ), а іноді й ця інформація відсутня - як-от у пінських матеріалах Р. Зінкевича (Zieńkiewicz 1851) (передрукованих у виданні Białoruś - Polesie О. Кольберra [Kolberg 1968]), де окреслено лише етнографічний регіон запису без зазначення конкретної говірки. Відсутність точної локалізації ускладнює використання цих матеріалів як діалектологічного джерела, обмежуючи його лише релятивним топографічним співвіднесенням матеріалів.

Сучасні фольклорні записи з чіткою паспортизацією, часто не містять важливих для лінгвістичних досліджень свідчень про компетенцію мовця, зокрема його освіту чи рід діяльності, що нерідко сприяє правильній кваліфікації мовних рис діалекту. Особливої ваги це набуває у випадку аналізу текстів, записаних від недавніх переселенців, які ще зберігають свій особливий мовний код, властивий материнській говірці. Приміром, у виданні ЕОСУ подано чимало текстів, записаних із переселенських середньополіських говірок (т. зв. чорнобильських), які подано як репрезентативні для населеного пункту, у якому вони нині побутують

\footnotetext{
2 Про методику записування фольклорного матеріалу див. праці О.Ю. Бріциної (2003; 2009).
} 
і який, що важливо, належить до іншого діалектного ареалу (власне, за відсутності текстів, записаних від корінних мешканців цих сіл), як-от, наприклад, перехідні говірки від східнополіських до середньонаддніпрянських - смт Баришівка, сс. Лукаші, Лук'янівка, Недра та ін. (EOCУ VII). У цьому випадку паспортизація текстів особливо актуальна, адже неврахування цієї інформації в лінгвістичних дослідженнях може призвести до хибних висновків в аналізі мовного матеріалу.

Отже, питання паспортизації та представлення у фольклорних виданнях різних соціолінгвістичних кваліфікаторів важливе не лише з погляду наукової етики, коли має бути збережено авторство тексту, твореного в момент оповіді, а й з огляду на те, що паспортизація уможливлює коректне використання фольклорних текстів у лінгвістичних дослідженнях, які неможливі без урахування локусу творення наративу, та проведення зіставних досліджень.

Методиці й методології записування фольклорного матеріалу присвятила чимало розвідок О.Ю. Бріцина, яка підкреслює, що сьогодні найбільш прийнятною видається текстологічна модель, що «передбачає не лише точне відтворення вербальної складової, а й опис середовища та обставин, за яких функціонує усний текст, манери оповідача, особливостей сприймання твору аудиторією, іiі реакцій» (Бріцина 2003, 26). Зауважимо, що позатекстові коментарі експлораторів нині поступово входять у практику підготовки власне діалектологічних зібрань текстів, коли їх укладачі коментують реакцію, емоції, поведінку мовців (див., напр., Аркушин 2007; 2012). Такий підхід дозволяє частково компенсувати в лінгвістичному аналізі «інформаційні втрати, неминучі під час графічного передання усного мовлення» (Гриценко 2015, 12): зокрема надсегментні явища, наприклад зміну

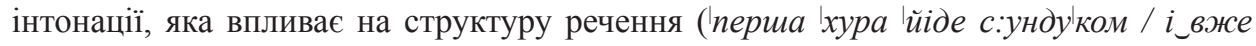
тако с'тукайут по_сундукови / так / (голосно) / nридан'е 'йіде! (Аркушин 2007, $254)$ - для виокремлення прямої мови); екстралінгвальні складники - наприклад, коли в комунікативній ситуації еліпсовані елементи ${ }^{3}$ в реченні компенсуються жестами, рухами оповідача (або ж останні передають додаткову інформацію), коли вони стають зрозумілі із загального акту комунікації, що, відповідно, не потребує розширених пояснень з боку мовця і зрозуміло адресатові (експлораторові) тощо; див. також: (Sicińska 2018, 156).

$* * *$

Певна річ, згадані позатекстові фактори безпосередньо позначаються на якості записаного фольклорного тексту, на його цінності та можливості використання в лінгвістичних дослідженнях. Водночас існує низка факторів, пов'язаних із власне текстом твору, його сутністю.

Вивчаючи тріаду «літературна мова - мова фольклору - діалект», дослідники наголошували на нетотожності мови фольклору й діалекту (напр., див.: Оссовецкий 1958, 173-179). Питання виникають у зв'язку з тим, які мовні одиниці (у широкому сенсі цього слова) та явища можна кваліфікувати як діалектні й такі, що маркують певну територію, а які з них - як стилістично зумовлені, властиві

\footnotetext{
3 Про семантичну компресію в усному наративі див.: Гриценко 2015, 24-26.
} 
фольклорному тексту як окремій формі побутування мови (див., напр.: Sierociuk 1990, 12), що, крім інформативної, виконують ще й естетичну функцію, відповідно породжуючи елементи, відсутні в розмовному діалектному мовленні. У зв'язку 3 цим можна виділити окремі обмеження на дослідження мови фольклору в контексті діалектології.

Насамперед до них належать тип організації мови - іï прозова чи віршована форма. Попри наявні формули (як-от у казках), прозовий текст, на відміну від поетичного, є більш варіативним, адже відводить оповідачеві більшу роль у конструюванні наративу, не підлягає тиску ритмомелодики та вимог римування (напр., про появу в російських піснях йотації, зумовленої особливостями вокальної манери відтворення тексту, див.: Богатырев 19624). Отже, можна очікувати на частішу відтворюваність у таких текстах власне діалектних рис, зокрема лексичних. Водночас дослідники наголошували на більшій консервативності віршованих фольклорних творів, більшій кількості в них архаїчних елементів - як змістових, так і формальних (Колесса 1938, 19-20).

У зв’язку з цим зберігає актуальність питання про те, які елементи можуть бути сталими, такими що залишаються й на новому місці побутування фольклорного твору (зокрема пісень ${ }^{5}$ ) у разі його міграції, а які можна вважати привнесеними ззовні й засвоєними. Наприклад, як зазначав Р. Якобсон, «ті елементи пісенного тексту, від втрати яких страждає його віршований лад, нерідко виявляють найбільший консерватизм» (Якобсон 1962, 87); інший фактор - престиж сусідніх говірок (Якобсон 1962, 87-88). Усе це ставить перед дослідником завдання зняття нашарувань, привнесених з іншого локусу, виявлення різночасових пластів твору, на підставі чого він може робити висновок про просторове співвіднесення мовних рис, засвідчених у творі народної словесності. Загалом особливості різних віршованих жанрів українського фольклору та діалектних особливостей мовлення їх виконавців - окрема складна й не розв'язана в українському мовознавстві проблема.

Диференціація мовного буття має місце й у фольклорних текстах залежно від жанру, на чому, зокрема, наголошував і Й.А. Оссовецький, зазначаючи, що в «кожному жанрі діалект реалізується в специфічних формах» (Оссовецкий 1958, 176). Жанрові ознаки фольклорних текстів накладають відбиток на особливості формування тексту, його зміст і структуру, а відтак - на ті діалектні риси, які дослідник може виявити в цих текстах. Наприклад, для вже згадуваних вище казок (насамперед чарівних), на відміну від легенд і переказів, властиві усталені ініціальні та фінальні словесні формули (ІУЛ, 84). Натомість народні наративи, перекази допускають варіантність у відтворенні першотексту (як стверджує Є. Бартмінський, у цьому випадку в народній пам'яті зберігається патерн, що, відповідно, утілюється в певній текстовій формі під час його витворення / відтво-

\footnotetext{
4 У контексті російського явища - йотації перед вокальним початком слова - П.Г. Богатирьов розглядає й українську лексему йуж, яка поширена в піснях Карпатського ареалу; щоправда, генеза карпатського йуж інша, це запозичення з польської мови, див.: ЕСУМ, VI, 520.

${ }^{5}$ На польському грунті вивченню співвідношення віршової форми, а саме народних пісень, та сучасних діалектів присвятив свою працю проф. С. Серотюк (Sierociuk 1990).
} 
рення (Bartmiński 1973, 40; також див.: Sicińska 2018, 156)), дають більше свободи оповідачеві в конструюванні наративу. Тому очікувано, що такі тексти більше відбивають особливості живого народнорозмовного середовища; у цьому пересвідчує ознайомлення 3 прозовими фольклорними формами, які відображають особливості різних українських говірок - подільських, середньонаддніпрянських, східнополіських тощо; докладніше див., напр.: (Колесса 1938, 529-564). Особливо виразно варіантність простежується у фольклорних творах «малих» жанрів, наприклад, прислів’ях і приказках, про що неодноразово зазначали діалектологи дослідники народної фразеології (див., напр.: Глуховцева 2014, 118-122); варіанти (найчастіше лексичні) представлені й у найбільшому зібранні прислів’їв та приказок М. Номиса (1864) та матеріалах І.Я. Франка (1901).

Водночас варто підкреслити, що настанови записувачів не завжди дозволяли точно зафіксувати й зберегти деякі творені оповідачем тексти окремих жанрів. Наприклад, І.Я. Франко, який стояв на позиції точного відтворення говіркових рис у фольклорних записах, виписуючи настанови для збирачів фольклору, допускав відступ від цього принципу на користь змістової точності відтворення інформації окремого типу: «Вірування і ліки можна передавати й своӥми словами [курсив мій - M.T.], але се належить виразно зазначити» (Франко 1982, 412). Очевидно, аналогічний принцип опису використано й у казках та оповідях з Волині, які О. Кольбергові передав невідомий житомирянин (Kolberg 1964, 412-450).

Певна річ, мовна диференціація фольклорного тексту за жанрами тісно пов'язана з іншим визначальним фактором - змістовими ознаками жанру та, відповідно, контекстом побутування фольклорного твору - диференціацією мовного буття самих носіїв говірок (родина, село, соціопрофесійне середовище, релігія, школа) як потенційних його виконавців / відтворювачів. Залежно від цього можна очікувати на вищу частотність вживання лексики тієї чи іншої групи, зокрема тематичної. Так, про відмінність мови билин з огляду на їхню тематику зауважував О.О. Шахматов, наголошуючи на використанні в цих творах великої кількості церковнослов'янізмів (див.: Якобсон, 88). Так само це стосується й інших жанрів, наприклад, українських колядок, які Ф. Колесса саме за тематикою (мотивами) поділяв на кілька основних груп - хліборобські, воєнні, фантастичні, любовного змісту та біблійні (Колесса 1938, 37-50). Очікувано, що саме в останньому циклі відзначено найбільшу кількість «книжної лексики», те саме стосується зібраних П. Чубинським релігійних пісень, у яких, цілком логічно, простежується чимало церковнослов'янської лексики (nатріарсі, боговозбранная Діва, Maты-отроковыцее, збавленніе, благодать, преблагая, пристол, гласъ тощо), давніх форм, нині рідко вживаних у живому мовленні (напр., окремих відмінкових форм - у руйъхъ, форм займенників - тя та ін.); велика кількість дієприслівників, не властивих спонтанному усному мовленню - взявши, привязавши, сорвавщи, ухвативши, бачучи тощо (Чубинскій 1872, 160-182). 
Отже, огляд різних фольклорних джерел та прийомів, засад їх формування як основи студій засвідчує їхню різну евристичну цінність для дослідників-лінгвістів не лише через відмінну «якість» фольклорного запису, а й через різні текстотвірні ознаки різних фольклорних текстів. Численні дослідження фольклору різних слов'янських народів засвідчують активне вживання у фольклорно-етнографічних текстах не лише живих діалектних рис (що верифікується залученням до аналізу сучасних записів фольклору), а й рис, які вже стали архаїчними для говірки, часом - перейшли до кола сталих фольклорних епітетів. Комплексне вивчення фольклорних текстів визначеного обширу відкриває для дослідника перспективи віднайдення давніх мовних рис, які у відповідному діалектному ареалі вже архаїзувалися, залучення ареалогічних дослідницьких процедур до аналізу мовних одиниць та явищ, виявлених у фольклорних текстах.

Навіть схематично окресливши найважливіші чинники, які накладають деякі обмеження на використання фольклорних джерел у діалектологічних дослідженнях, зауважимо наявність високого евристичного потенціалу народнопісенних текстів, ширше - народної словесності для діалектологічних студій; останнє підтверджує і пожвавлення інтересу до таких джерел серед українських лінгвістів. У перспективі актуальним залишається опрацювання якнайширшого масиву таких текстів з різних українських обширів та теоретичне осмислення цього матеріалу.

\section{Література}

Аркушин Г. [Arkushyn Н.] (2012), Голоси з Берестейщини (Тексти) [Holosy z Beresteishchyny (Teksty)], Луцьк.

Аркушин Г. [Arkushyn Н.] (2007), Голоси з Підляшшя (Тексти) [Holosy z Pidliashshia (Teksty)], Луцьк.

АУМ, Атлас української мови: в 3 m., т. 2: Волинь, Наддністрянщина, Закарпаття $i$ суміжні землі [Atlas ukrainskoi mоvy: $v 3$ t., t. 2: Volyn, Naddnistrianshchyna, Zakarpattia i sumizhni zemli], Київ 1988.

Богатырев П. Г. [Bohatyrev P. G.] (1962), О языке славянских народных песен в его отношении $к$ диалектной речи [O yazyke slavyanskih narodnyh pesen $v$ ego otnoshenii $k$ dialektnoj rechi], «Вопросы языкознания», № 3, с. 75-86.

Борисенко В. [Borysenko V.] (2011), Така житка... Культура повсякдення українців Чорнобильського Полісся (за матеріалами етнографічної експедиції 1994 p.) [Taka zhytka... Kultura povsiakdennia ukraintsiv Chornobylskoho Polissia (za materialamy etnohrafichnoi ekspedytsii 1994 r.)], Київ.

Бріцина О.Ю. [Britsyna O.Yu.] (2003), Сучасні аспекти методики збирання народної прози [Suchasni aspekty metodyky zbyrannia narodnoi prozy], «Народна творчість та етнографія», № 3, с. 24-34.

Бріцина О.Ю. [Britsyna О.Yu.] (2009), Текстологічні та едиційні рімення у фольклористииі: українська наукова традиція й новітні методологічні течії [Tekstolohichni ta edytsijni rishennia u folklorystytsi: ukrainska naukova tradytsiia $i$ novitni metodolohichni techii], «Вісник Львівського університету. Серія філологічна», вип. 47, с. 83-93. 
Глуховцева I.Я. [Hlukhovtseva I.Yа.] (2014), Варіанти фразеологічних одиниць в українських східнослобожанських говірках [Varianty frazeolohichnykh odynyts $v$ ukrainskykh skhidnoslobozhanskykh hovirkakh], [в:] Діалекти в синхронії та діахроніï: загальнослов'янський контекст [Dialekty v synkhronii ta diakhronii: zahalnoslovianskyi kontekst], Київ, с. 118-122.

Гнатюк В. [Hnatiuk V.] (1897), [Передмова] [Peredmova], [в:] Етнографічний збірник, т. 1: Лєтенди і новелї, т. 3: Етнографічні матеріали з Угорської Руси, зібрав В. Гнатюк. [Еtпоhrafichnyi zbirnyk, t. 1: Liegendy i noveli, t. 3: Etnohrafichni materialy z Uhorskoi Rusy. zibrav V. Hnatiuk], Львів.

Грицак М.А. [Hrytsak M.A.] (2017), Матеріали до Словника українських говірок Закарпатської області [Materialy do Slovnyka ukrainskykh hovirok Zakarpatskoi oblasti], вип. 1: $A-Б$, за ред. П.Ю. Гриценка, Київ.

Гриценко П. [Hrytsenko P.] (2003), Тексти як джерело дослідження украӥнських говірок Pумуніï [Teksty yak dzherelo doslidzhennia ukrainskykh hovirok Rumunii], [в:] М. Павлюк, I. Робчук, Українські говори Румунії. Діялектні тексти [M. Pavliuk, I. Robchuk, Ukrainski hovory Rumunii. Diialektni teksty], Едмонтон - Львів - Нью-Йорк - Торонто.

Гриценко П.Е. [Hrytsenko P.Ye.] (2015), Феномен диалектного явления: онтология и гносеология [Fenomen dialektnogo yavleniya: ontologiya i gnoseologiya], [в:] Исследования по славянской диалектологии, т. 17: Судьба славянских диалектов и перспективы славянской диалектологии [Issledovaniya po slavyanskoj dialektologii, t. 17: Sudba slavyanskih dialektov i perspektivy slavyanskoj dialektologii], Москва, с. 9-59.

Гриценко П.Ю. [Hrytsenko P.Yu.] (2014), Про один тип джерел сучасних діалектологічних cmydiŭ [Pro odyn typ dzherel suchasnykh dialektolohichnykh studii], [в:] Діалекти в синхронії та діахронії: загальнослов'янський контекст [Dialekty v synkhronii ta diakhronii: zahalnoslovianskyi kontekst], Київ, с. 145-154.

ЕОСУ VII, Етнографічний образ сучасної України. Корпус експедииійних фольклорно-етнографічних матеріалів, т. 7: Господарські заняття, промисли та ремесла [Etnohrafichnyi obraz suchasnoi Ukrainy. Korpus ekspedytsiinykh folklorno-etnohrafichnykh materialiv, t. 7: Hospodarski zaniattia, promysly ta remesla], Київ, 2017.

ЕОСУ Х, Етнографічний образ сучасної Украӥни. Корпус експедичійних фольклорно-етнографічних матеріалів, т. 10: Традииійне повсякденне та обрядове вбрання [Etnohrafichnyi obraz suchasnoi Ukrainy. Korpus ekspedytsiinykh folklorno-etnohrafichnykh materialiv, t: 10: Tradytsiine povsiakdenne ta obriadove vbrannia], Київ, 2018.

ЕСУМ, Етимологічний словник української мови: в $7 \mathrm{~m}$. [Etymolohichnyi slovnyk ukrainskoi movy: $v 7$ t.], т. VI, за ред. О.С. Мельничука, Київ, 2006.

ІУЛ, Ткачук Р.Ф. [Tkachuk R.F.] (2013), Усна словесність [Usna slovesnist], [в:] Icmopiя української літератури [Istoriia ukrainskoi literatury], т. 1, Київ, с. 73-88.

Колесса Ф. [Kolessa F.] (1938), Украӥнська усна словесність [Ukrainska usna slovesnist], Львів.

Кравченко В. [Kravchenko V.] (2009), Зібрання творів та матеріали з архівної спадщини [Zibrannia tvoriv ta materialy z arkhivnoi spadshchyny], т. 2, упор. О. Рубан, Київ.

ЛАНП, Назарова Т.В. [Nazarova T.V.], Лінгвістичний атлас Нижньої Прип'яті [Linhvistychnyi atlas Nyzhnoi Prypiati], Київ, 1985.

HEC, Глушко М., Хомчак Л. [Hlushko M., Khomchak L.] (2017), Надсяння: традииійна культура і побут (етнолінгвістичні скарби) [Nadsiannia: tradytsiina kultura i pobut (etnolinhvistychni skarby)], Львів. 
Номис, Украінські приказки, прислівъя и таке инше. Збірники О.В. Марковича и других, спорудив М. Номис [Ukrainski prykazky, pryslivia i take inshe. Zbirnyky O.V. Markovycha $i$ druhykh, sporudyv M. Nomys], C.-Петербург, 1864.

Оссовецкий И.А. [Ossovetskyi I.A.] (1958), Язык фольклора и диалект [Yazyk folklora y dyalekt], [в:] Основные проблемы эпоса восточных славян [Osnovnye problemy ероsa vostochnyh slavyan], Москва, с. 172-190.

СМФ, Сборникъ матеріаловъ по малорусскому фольклор, собралъ А.Н. Малинка [Sbornik materialov po malorusskomu folkloru, sobral A.N. Malinka], Черниговъ, 1902.

Франко I.Я. [Franko I.Yа.] (1901), Галицько-руські народні приповідки [Halytsko-ruski narodni prypovidky], вип. 1 (А-Відати), [в:] Етнотрафічний збірник [Etnografichnyi zbirnyk], т. Х, Львів.

Франко І.Я. [Franko I.Yа.] (1982), До збирачів етнографічних матеріалів [Do zbyrachiv etnohrafichnykh materialiv], [в:] Франко І.Я. Зібрання творів у n'ятдесяти томах, т. 35: Літературно-критичні праці (1903-1905) [Franko I.Ya. Zibrannia tvoriv u piatdesiaty tomakh, t. 35: Literaturno-krytychni pratsi (1903-1905)], Київ, с. 412-414.

Франко I.Я. [Franko I.Ya.] (1980), Przyczynek do etnografii ludu ruskiego na Wotyniu, [в:] Франко І.Я. Зібрання творів у п'ятдесяти томах, т. 27: Літературно-критичні праиі (1886-1889) [Franko I.Ya. Zibrannia tvoriv u piatdesiaty tomakh, t. 27: Literaturno-krytychni pratsi (1886-1889)], Київ, с. 210-215.

Чубинскій П. [Chubynskii Р.] (1872), Общее предисловіе къ матеріаламъ и изсльдоованіямъ, собраннылъ П.П. Чубинскимъ [Obshchee predislovie $k$ materialam i izsledovaniyam, sobrannym P.P. Chubinskim], [в:] Труды этнографическо-статистической экспедиціи въ Западно-Русскій край, снаряженной Императорскимъ русскимъ географическимъ обществомъ. Юго-Западный отдъль. Матеріаль и изсльдованія, собранныя д. чл. П.П. Чубинскимъ [Trudy etnografichesko-statisticheskoj ekspedicii v Zapadno-Russkij kraj, snaryazhennoj Imperatorskim russkim geograficheskim obshchestvom. Yugo-Zapadnyj otdel. Materialy i izsledovaniya, sobrannyya d. chl. P.P. Chubinskim], т. 1, С.-Петербургъ, с. XI-XX.

Якобсон P.O. [Yakobson R.O.] (1962), О соотношении между песенной и разговорной народной речью [O sootnoshenii mezhdu pesennoj i razgovornoj narodnoj rechyu], «Вопросы языкознания», № 3, с. 87-90.

Bartmiński J. (1973), O języku folkloru, Wrocław - Warszawa - Kraków - Gdańsk.

Kolberg O. (1964), Dzieła wszystkie, t. XXXVI: Wołyń, Wrocław - Poznań.

Kolberg O. (1968), Dzieła wszystkie, t. LII: Białoruś - Polesie, Wrocław - Poznań.

Sicińska K. (2018), Regionalne i ponadregionalne cechy podhalańskich pieśni zbójnickich, «Rozprawy Komisji Językowej ŁTN», t. LXV, s. 155-180.

Sierociuk J. (1990), Pieśń ludowa i gwara, Lublin.

Zieńkiewicz R. (1851), Piosenki gminne ludu pińskiego, Kowno. 